International Journal of Advanced Chemistry, 2(2)(2014) 148-161
International Journal of Advanced Chemistry
Journal home page: $\begin{gathered}\text { www.sciencepubco.com/index.php/IJAC } \\ \text { doi: } 10.14419 / \text { ijac.v2i2.2661 } \\ \text { Research Paper }\end{gathered}$

\title{
The anticancer potential of various substituted pyridazines and related compounds
}

\author{
Mohammad Asif \\ Department of pharmacy, GRD (PG) IMT, Dehradun, India \\ E-mail: aasif321@gmail.com
}

\begin{abstract}
Pyridazine nucleus exhibited immense pharmacological activities. Pyridazine nucleus is present in various compounds that possess remarkable pharmacological activities. Various pyridazinone compounds have antitumor activity. Some of them pyridazinone derivatives bearing different moieties were exhibited excellent anticancer activity toward human cancer cell lines. They showed remarkable activity against leukemia, non-small cell lung cancer, colon, central nervous system, melanoma, ovarian and breast cancer cell lines. These compounds were act by different mechanism.
\end{abstract}

Keywords: Pyruvate Kinase; Anti-Cancer; Pyridazines; Biological Activities; Cytotoxicity.

\section{Introduction}

The pyridazine compounds are possess almost all types pharmacological activities such as antidepressant, antihypertensive, antithrombotic, anticonvulsant, cardiotonic, antibacterial, diuretic, anti-HIV, hepatoprotective and protaglandin inhibitors (Abdelrazek et al., 2006; Wang et al., 2008; Allerton et al., 2009; Bansal et al., 2009; Costas et al., 2010; Bashir et al., 2010; Zhou et al., 2011; Unsal tan et al., 2011; Faidallah et al., 2011; Husain et al., 2011). It has also been reported that pyridazinone derivative also have remarkable anticancer activity. The present review focuses on pyridazines and related compounds which possess potential anticancer activities (Pau et al., 2009; Abd El-Ghaffar et al., 2011). Pyridazine derivatives represent a active classes of compounds that possessing a wide spectrum of biological activities (Asif and Singh 2010; Asif. 2012).

Among all diseases, cancer ranks high as a major killer worldwide. Among diseases, cancer is not a single pathological state but a broad group of diseases characterized by a high proliferative index and the spread of aberrant cells from their site of origin (Fidler. 2003). Clinically, the therapeutic treatment of cancer is a combination of surgery and/or radiotherapy with chemotherapy (Chabner et al., 2005; Gilchrest, et al., 2009). Current chemotherapy consists of cytotoxic (cell-killing) agents and anti-hormonal drugs, which reduce the proliferation of the tumors (Chabner et al., 2005; Gilchrest, et al., 2009). The therapeutic use of anticancer drugs is complicated by systemic toxicity, usually observed in the bone narrow, the gastrointestinal (GI) tract and hair, and by development of resistance. Therefore, the search for novel chemical structures with broader therapeutic windows and acceptable resistance profiles is being actively pursued. The continued commitment to the demanding task of discovering new anticancer agents remains critically important. A large number of pyridazine derivatives attract considerable attention have recently been reported to show substantial antitumor activity. There are a variety of mechanisms of their antitumor action, most of them poorly understood at this moment. It is believed that carbonic anhydrase inhibition, cell cycle arrest in the G1 phase, disruption of microtubule assembly, functional suppression of the transcriptional activator, and angiogenesis (matrix metalloproteinase, MMP) inhibition may be among such relevant mechanisms of these anticancer compounds. Some of these derivatives are currently being evaluated in clinical trials, and there is much optimism that they may lead to novel anticancer drugs, devoid of the side effects of the presently available anticancer drugs (Rathishet al., 2012). In discovering anticancer compounds, a remarkable role is played by pyridazine moiety (Pinna, et al., 2009; Cignarella et al., 1989; Cignarella et al., 1990; Pinna et al., 1997). Pyridazinone derivatives also possess affinity for benzodiazepine receptors and the ability to inhibit the human matrix metalloproteinase (Pinna et al., 2000) and aldose reductase enzymes (Costantino et al., 1996; Pau, et al., 2004).

\section{Cyclin-dependent kinases (CDKs) Inhibi- tors}

Cyclin-dependent kinases (CDKs) are a family of serine/threonine kinases that regulate the cell division cycle phases, apoptosis, transcription, and differentiation in addition to other functions in the nervous system. CDK inhibitors have garnered attention recently for their potential as anticancer therapeutics. Pyrazolopyridazine was identified as a potent inhibitor of CDK1/cyclin B and shown to have selectivity for the CDK family. Analogues of the Pyrazolopyridazine compound have been shown antitumor activities. This prompted to synthesize a new series of pyrazolo[3,4-c]pyridazine analogues to improve potency against the CDK family while maintaining a favorable selectivity profile. A molecular model of the complex between the pyrazolopyridazine compound and the CDK2 ATP binding site has been built. The stability of the resulting complex has been assessed by molecular dynamics simulations and has been rationalized on the basis of the proposed binding mode for compound (Brana et al., 2005). 


\section{Glycogen synthase kinase-3 (Gsk-3) inhibi- tors}

Pyrazolopyridazine is a potent inhibitor of glycogen synthase kinase-3 (GSK-3) and CDK2/cyclin A (Witherington et al. 2003) and showed excellent selectivity against the majority of the tested kinases. As in the case of CDKs, this type of kinase is involved in cancer and neurodegenerative diseases (Knockaert et al. 2002; Brana et al. 2005).

\section{Pyruvate kinase}

Cancer cells have distinct metabolic needs that are different from normal cells and can be exploited for development of anti-cancer therapeutics. Activation of the tumor specific M2 form of pyruvate kinase (PKM2) is a potential strategy for returning cancer cells to a metabolic state characteristic of normal cells. Here, we describe activators of PKM2 based upon a substituted thieno [3, 2-b] pyrrole $[3,2-d]$ pyridazinone scaffold. The synthesis of these agents, structure activity relationships, analysis of activity at related targets (PKM1, PKR and PKL) and examination of aqueous solubility are investigated. These agents represent the second reported chemotype for activation of PKM2 (Jiang et al., 2010).

\section{Anticancer activity of natural pyridazines agents}

A series of 5, 6-diphenylpyridazin-3-one (DPP) derivatives was examined for interactions with calf brain tubulin, caused significant mitotic effects in intact animals, while others had activity against marine P388 leukemia. In L1210cells several DPP derivatives caused a rise in the mitotic index which correlated well with the cytotoxicity of the drugs. Active DPP derivatives markedly stimulated tubulin-dependent guanosine triphosphate hydrolysis and inhibited tubulin polymerization or induced tubulin oligomer formation, depending on specific reaction conditions. These agents did not interfere with the binding to tubulin of radio labeled colchicine, vinblastine, maytansine, or guanosine triphosphate. They thus appear to bind at a previously undescribed site on the tubulin molecule. Some DPP derivatives have significant herbicidal activity, causing mitotic disruption and a rise in the mitotic index in seedling root tissues. Although the DPP derivatives most toxic to plant tissues differ from those most active in inhibiting calf brain tubulin polymerization, virtually all active compounds bear a nitrile substituent at position 4 of the pyridazinone ring. Most active derivatives also bear substituents of varying structure at position 2 of this ring. The phenyl rings in the most active herbicidal DPP derivatives either are unsubstituted or bear fluorine atoms. In contrast, interactions with calf brain tubulin are sub stantially enhanced if the phenyl rings bear chlorine substituents. The antitumor activity of pyridazines or phthalazines related compound, such as olivacine type. The in-vitro screening for cytotoxic activity, not only olivacine type compounds (indolylpropylsubstituted 1, 2-diazines) showed significant tumor cell-growth inhibition. Some 3-(indol-1-yl) prop-1-yn-1-yl-substituted phthalazines and related azines exhibited significant in-vitro antitumor activity. The preliminary screening tested at a concentration of $3.16 \mu \mathrm{g} / \mathrm{mL}$ for antitumor activity by using the in-vitro XTT assay (Norbert and Eddy. 2002). A series of b-fused carbazoles structurally related to pyrido [4, 3-b] carbazole-type alkaloids. The compound represents a new 3-aza analogue of the antitumor natural product, olivacine. A pyrido[4, 3-b] carbazole-type alkaloids, the antitumor natural product, olivacine (Haider N, Sotelo. 2002), represents a new 3-aza analogue of the antitumor natural product, olivacine and their structural modifications will be carried out, aiming at an enhancement of antineoplastic activity (Norbert and Eddy 2002).

Several DPP derivatives were active in reducing blood pressure in hypertension (Buchman, et al., 1980), some DPP derivatives dis- played herbicidal activity (Mizens, et al., 1984; Mizens, et al., 1985). A number of the agents were screened for antineoplastic activity, and a significant increase in survival of mice given simultaneous injections of P388 leukemia cells and selected DPP derivatives was observed. Since, antineoplastic drugs of uncertain mechanism of action for their effects on tubulin-dependent GTP hydrolysis (Hamel, and Lin. 1983; Batra, et al., 1985) to identify new antimitotic agents. They were found to stimulate GTP hydrolysis dramatically. In particular, they were antimitotic agents in mammalian cells, determine their effects on tubulin polymerization, locate their binding site on tubulin, and determine structurefunction correlations among presently available compounds. The DPP derivatives are a class of antimitotic drugs, many of which interact directly with bovine brain tubulin. Their effects in inhibiting flagellar regrowth and inducing mitotic disruption derive from an analogous interaction with plant tubulin. Specific DPP derivatives have inhibitory activity only with one class of organisms. Those most active in plant tissues interact only weakly with bovine tubulin and vice versa. In herbicidal activity, compounds with unsubstituted phenyl rings were highly active, as were those with fluorine substituents. Chlorine groups on the two phenyl rings eliminated herbicidal activity. The opposite is the case for interactions of DPP derivatives with bovine tubulin. The interactions of the DPP derivatives with tubulin are reminiscent of colchicine as stimulating tubulin-dependent GTP hydrolysis even as they inhibit the microtubule assembly associated with GTP breakdown (Hamel 1984; Batra, et al., 1986). However, these drugs do not inhibit the binding of colchicine to tubulin. The DPP derivatives are also reminiscent of the Vinca alkabids in that they inhibit microtubule assembly and induce tubulin oligomer formation (Luduena, et al., 1984). The DPP derivatives bind to a previously undescribed site on tubulin, for they also do not inhibit the binding of guanine nucleotides at the exchangeable GTP site. Some of the DPP derivatives (particularly NSC 351478) were effective in the treatment of P388 leukemia in mice. The substituents at position 2 of the pyridazinone ring do not fall into a clear pattern; alterations at this position can have major effects on the activity of the resulting compounds. More specific was the effect of chlorinating the phenyl rings. Position 4' seems most important, but second chlorine at position 3 ' further enhanced in vitro inhibition of microtubule assembly. Position 4 of the pyridazinone ring is also of major importance. Virtually all compounds which inhibit polymerization of bovine tubulin or which have herbicidal activity bear a nitrile group at this position. A single compound of this group (analogous to NSC 362449 , but bearing chlorine instead of a nitrile at position 4) has had activity. This compound was about one third as effective as NSC 362449 in inhibiting microtubule assembly. Thus, while the nitrile group cannot be considered essential for inhibitory activity in the DPP derivative series, it is none the less of major importance. It appears that a substituent is required at position 4 and that it must be relatively small (Hamel, and Lin. 1984).<smiles>Cc1c2[nH]c3ccccc3c2cc2c(CO)n[nH]c(=O)c12</smiles><smiles>Cc1n[nH]c(=O)c2c(C)c3[nH]c4ccccc4c3cc12</smiles> 
<smiles>CC1=NNCc2c1cc1c([nH]c3ccccc31)c2C</smiles>

Fig. 1: Structurally Related Compounds to the DPP Derivatives and Which Do Not Inhibit In Vitro Microtubule Assembly.

Olivacine (1, 5-dimethyl-6H-pyrido [4, 3-b] carbazole) is a member of the pyridocarbazole family of alkaloids. It was first isolated from the bark and stem of Aspidosperma olivaceum and it has been found to possess similar antitumor activity as its 5, 11dimethyl isomer, ellipticine, and related compounds like 9methoxyellipticine (Gribble. 1990). As the main mechanism of these agents' antineoplastic action, a stabilization of the "cleavable complex" which is formed between DNA and the enzyme, topoisomerase II, is generally accepted, although additional mechanisms have been discussed for some pyridocarbazoles, e.g. reactivation of the lost functionality of the p53 protein. Based on the naturally occurring lead compounds, numerous modifications of this system have been studied, leading to the development of drugs like elliptinium, datelliptium, retelliptine, or pazelliptine. Recently, the highly potent olivacine analogue, S16020, has attracted considerable attention due to its apparent ability to circumvent P-glycoprotein-mediated multidrug resistance (Haider, et al., 1999; Haider. 2002). Among the structural variations, incorporation of an additional nitrogen atom into the tetracyclic skeleton, like in the case of 9-aza-ellipticine or pazelliptine. Based on previous investigations in the 3-aza-ellipticine series, several pyridazino $[4,5-b]$ carbazoles, some of which exhibited significant antitumor activity (Haider, et al., 1998; Spreitzer, et al., 2007; Haider, and Käferböck. 2004). We now became interested in the synthesis of the new molecule, 1,5-dimethyl-6H-pyridazino[4,5b]carbazole derivatives, as a 3-aza isoster of olivacine, which was required as a reference compound (Sims, et al., 2003; McGrath, et al., 2005; Teague. 2003). Among the structural variations which have been described so far, there are several examples for incorporation of an additional nitrogen atom into the tetracyclic skeleton, like in the case of 9-aza-ellipticine or pazelliptine. Based on previous investigations in the 3 -aza-ellipticine series, recently reported the synthesis of several pyridazino[4,5-b]carbazoles, some of which exhibited significant antitumor activity. In the course of ongoing research, synthesis of 1,5-dimethyl-6H-pyridazino[4,5b]carbazole derivative, as a 3-aza isoster of olivacine, for the preparation of 1,5-dialkyl-6Hpyridazino[4,5-b]carbazoles, which is based on a ring transformation of 5-acyl-11H-pyrido[4,3a]carbazoles. However, this sequence inherently leads to 5-ethylsubstituted pyridazino[4,5-b]carbazoles. Here, report on a short synthesis of 3-aza-olivacine and on the results of an initial in-vitro testing for antitumor activity. In a first approach to the 1, 5disubstituted pyridazino[4,5-b]carbazole skeleton, we investigated the selective addition of methyllithium to an appropriate 1methylcarbazole-2,3-dicarboxylic acid derivative. We employed the protected N-phenylimide as the electrophile.<smiles>[R]c1n[nH]c(=O)c2c(C)c3[nH]c4ccccc4c3cc12</smiles>

1a: $\mathrm{R}=\mathrm{CH} 3$<smiles>Cc1ncc(C(N)=O)c(C)c1C</smiles>

$1 b$<smiles>Cc1nnc(Cl)c2c(C)c3[nH]c4ccccc4c3cc12</smiles><smiles>[R]C1=NNCc2c1cc1c(C)c-1[nH]c1ccccc21</smiles>

$3 \mathrm{R}=\mathrm{CH}_{3} 4 \mathrm{R}=\mathrm{H} 5 \mathrm{R}=\mathrm{CH}_{2} \mathrm{OH}$

The pyridazinone (1a) was converted into the chloro compound (2). Preliminary evaluation of the cytotoxic activity of 3azaolivacine (3) towards four human tumor cell lines, using the XTT assay, showed significant effects only at a relatively high concentration of $3.16 \mathrm{~m} \mathrm{~g} / \mathrm{ml}$, whereas at lower concentrations no dose-dependent activity was observed. For all cell lines, growth inhibitory activity of 3 was found to exceed that of the 5monomethyl congener (3), the synthesis of which we had reported recently. The compound (3) was a new 3-aza bioisoster of the natural product, olivacine (Haider and Sotelo.2002). The antitumor activity of polycyclic hetarenes, especially condensed carbazoles of the ellipticine/olivacine type (Haider, et al., 1999; Fidesser, et al., 2001; Haider. 2002) and polycyclic quinones (Spreitzer, et al., 2001; Spreitzer, and Puschmann. 2007). The pentacyclic ellipticine analogues (Haider, and Käferböck. 2004) were exhibited invitro cytotoxic activity, also one of the intermediates, namely 1-[3-(indol-1-yl) prop-1-yn-1-yl]phthalazine, showed significant tumor cell-growth inhibition. Therefore, this compound with a 1,3-disubstituted propyne unit as the central element was selected as a new lead structure for further exploratory investigations (Haider et al., 2007). Tricyclic molecules containing the thienocyclohepta pyridazinone ring system, a number of $2 \mathrm{~N}$-substituted-hexahydrothienocycloheptapyridazinone derivatives were exhibited anticancer activity.<smiles></smiles>

Fig. 2: Synthesis of Bridged Ellipticine/Olivacine Analogues 
<smiles>[Z1]CCCc1nnc([R2])c([R3])c1CCn1ccc2cc([R7])ccc21</smiles><smiles>[R]c1ccc2c(ccn2CC#Cc2[Y]([H])c([R2])c3ccccc23)c1</smiles>

$\mathrm{R}_{1}=\mathrm{H}, \mathrm{OCH}_{3}, \mathrm{Br}, \mathrm{COOCH}_{3} \mathrm{R}_{2}=\mathrm{H}, \mathrm{CH}_{3}, \mathrm{Ph} ; \mathrm{X}=\mathrm{I}, \mathrm{Br}$<smiles>[R2]c1ccc2c(ccn2CC#Cc2nnc([R2])c3ccccc23)c1</smiles><smiles>[R7]c1ccc2c(c1)CCN2CC#Cc1nnc([R])c2ccccc12</smiles>

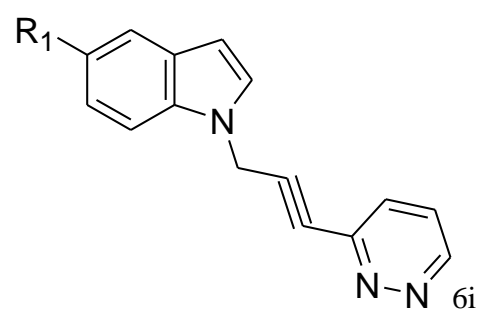

6a $\mathrm{R}_{1}=\mathrm{CH}_{3} \mathrm{O}, \mathrm{R}_{2}=\mathrm{CH}_{3} ; 6 \mathrm{~b} \mathrm{R} 1=\mathrm{CH}_{3} \mathrm{O}, \mathrm{R}_{2}=\mathrm{C}_{6} \mathrm{H}_{5} ; 6 c \mathrm{R}_{1}=\mathrm{H}$, $\mathrm{R}_{2}=\mathrm{H}$; 6f $\mathrm{R}_{1}=\mathrm{Br}, \mathrm{R}_{2}=\mathrm{H}$;

$6 \mathrm{~g} \mathrm{R}_{1}=\mathrm{CH}_{3} \mathrm{CO}, \mathrm{R}_{2}=\mathrm{H} ; 6 \mathrm{~h} \mathrm{R} \mathrm{R}_{1}=\mathrm{CH}_{3} \mathrm{O}, \mathrm{R}_{2}=\mathrm{H} ; 6 \mathrm{i} \mathrm{R}=\mathrm{CH}_{3} \mathrm{O} ; 6 \mathrm{j}$ $\mathrm{R} 1=\mathrm{H}, \mathrm{R}_{2}=\mathrm{H}$

\section{Anticancer activity of synthetic pyridazines}

The antitumor activity of pyridazine or phthalazine compounds, heterocyclic annelated pyridazines and other related compounds attract considerable attention. Triazolo-pyridazine derivatives are used as adenine receptor ligands and evaluated as in vitro antitumor activity. The 6-substituted pyridazinone $(7,8)$ and pyridazino-fused ring systems, triazolo [4, 3-b]pyridazinones (9$15)$ were exhibited in-vitro antitumor activities. The compounds 915 have been evaluated as cytotoxic agent against tumor cells. In vitro evaluation of the cytotoxic effect of compounds 11 and 12 shows that both of these products are cytotoxic to the Hep cell line in a dose-dependent manner, with $\mathrm{IC}_{50}$ values of $20.76 \mu \mathrm{g} \mathrm{ml}^{-1}$ and $9.2 \mu \mathrm{g} \mathrm{ml}-1$, respectively. The cytotoxic effect of these products is weaker than that induced by adriamycin $\left(\mathrm{IC}_{50}: 1.2 \mu \mathrm{g} \mathrm{ml}^{-1}\right)$. The result showed that compound 12 was more cytotoxic than compound 11. The triazolo[4,3-b]pyridazinones showed antiproliferative activities. Compound 13 exhibits significant cytotoxicity against the Hep cell line (Rakib et al., 2006).

$6 c$

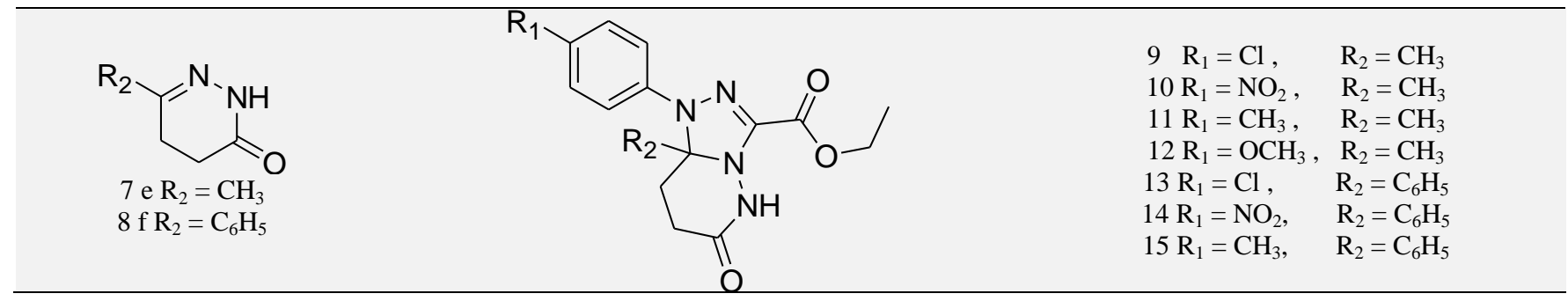

Some derivatives of pyrrolo [3, 4-d] pyridazinone modified at the pyrrole and pyridazine rings were exhibited in vitro anticancer activity. Few compounds assayed blocked the cell cycle regulating CDK1/cyclin B kinase, were active in anticancer screening (Malinka et al., 2004). The 1, 2, 3, 4-tetrahydro-6-substituted-2, 5, 7-trimethyl-6H-pyrrolo [3, 4-d] pyridazin-1,4-ones, pharmacological screening two of four pyrrolo [3, 4-d] pyridazinones were active as cystostatic agents (Malinka. 2001). A series of 3 (indol-1-yl) prop-1-yn-1-yl-substituted phthalazines and related azines was prepared by palladium-catalyzed cross-coupling of appropriate halo-azines and N-propargylindoles. Some compounds exhibited significant in-vitro antitumor activity (Haider et al. 2007).

Cyclin-dependent kinases (CDKs) are a family of serine/threonine kinases that regulate the cell division cycle phases, apoptosis, transcription, and differentiation in addition to other functions in the nervous system (Knockaert, et al., 2002). Each CDK associates with a specific cyclin regulatory partner to generate the active catalytic complex. Owing to both their central role in the cell cycle and their misregulation in a number of cancers (Malumbre and Barbacid. 2001) and neurodegenerative disorders, CDK inhibitors have garnered attention recently for their potential as anticancer therapeutics (Huwe, et al., 2003; Sielecki, et al., 2000). The search for small-molecule inhibitors of CDKs has already led to the dis- covery of several classes of compounds with high structural diversity (Knockaert, et al., 2002; Huwe, et al., 2003; Sielecki, et al., 2000). Only reports on the clinical trial of flavopiridol and UCN01 as cancer therapeutics are available (Senderowicz, et al., 1998; Sedlacek, et al., 1996; Akinaga, et al., 2000), but several other CDK inhibitors are currently making their way in the clinic. Despite striking chemical diversity, most CDK inhibitors share common properties (Witherington, et al., 2003). Thus, they are essentially low molecular weight, flat, hydrophobic heterocycles and act by competing with ATP for binding in the kinase ATP binding site. Pyrazolopyridazine 16a was identified in a high throughput screening as a potent inhibitor of CDK1/ cyclin B. Subsequent screening of this hit against other kinases revealed the compound to have selectivity for the CDK family. This prompted us to synthesize a new series of pyrazolo[3,4-c]pyridazine analogues of $16 \mathrm{a}$ in an attempt to improve potency against the CDK family while maintaining a favorable selectivity profile and to carry out a structure activity relationship study. The emphasis has been put on the molecular modulation. Specifically, (a) different substituents in the aromatic system at C-4 and C-5 have been introduced, (b) phenyl rings have been substituted by other groups, (c) the amino group at the $\mathrm{C}-3$ position has been substituted by other functions, and (d) different substituents have been introduced at position 1 , while pyrazolopyridazine $16 \mathrm{a}$ as a potent in- 
hibitor of glycogen synthase kinase-3 (GSK-3) and CDK2/cyclin A. In this work, this compound also showed excellent selectivity against the majority of the tested kinases. This result is not unexpected given the high homology between these two kinases and CDK1. GSK-3 has a major role in the regulation of the cell cycle, transcription, and insulin action. As in the case of CDKs, this type of kinase is involved in cancer and neurodegenerative diseases and it has also been used as a target to identify small molecular weight pharmacological inhibitors of potential therapeutic interest. Therefore, inhibitors that show dual specificity for these kinases could be useful in the treatment of cancer (Knockaert, et al., 2002; Meijer, et al., 2004; Brana et al., 2005).<smiles>Nc1n[nH]c2nnc(-c3ccccc3)c(-c3ccccc3)c12</smiles>

16a CDK1/cyclin B: $\mathrm{IC}_{50}=6.1 \mu \mathrm{M}, \mathrm{KDR}: \mathrm{IC}_{50}>50 \mu \mathrm{M}, \mathrm{LCK}: \mathrm{IC}_{50}>50 \mu \mathrm{M}$

\begin{tabular}{|c|c|c|c|c|}
\hline & Compounds & $\mathrm{R}_{1}=\mathrm{R}_{2}$ & Compounds & $\mathrm{R}_{1}=\mathrm{R}_{2}$ \\
\hline & $16 \mathrm{a}$ & $\mathrm{R}_{1}=\mathrm{R}_{2}=\mathrm{C}_{6} \mathrm{H}_{5}$ & $16 \mathrm{~h}$ & $\mathrm{R}_{1}=\mathrm{R}_{2}=2$-furyl \\
\hline & $\begin{array}{l}16 \mathrm{~b} \\
16 \mathrm{c} \\
16 \mathrm{~d} \\
16 \mathrm{e} \\
16 \mathrm{f} \\
16 \mathrm{~g}\end{array}$ & $\begin{array}{l}\mathrm{R}_{1}=\mathrm{R}_{2}=\mathrm{p}-\mathrm{C}_{6} \mathrm{H}_{5} \mathrm{C}_{6} \mathrm{H}_{4} \\
\mathrm{R}_{1}=\mathrm{R}_{2}=\mathrm{p}-\mathrm{NO}_{2} \mathrm{C}_{6} \mathrm{H}_{4} \\
\mathrm{R}_{1}=\mathrm{R}_{2}=\mathrm{p}-{ }^{\mathrm{B}} \mathrm{Bu} \mathrm{C} \mathrm{C}_{6} \mathrm{H}_{4} \\
\mathrm{R}_{1}=\mathrm{R}_{2}=\mathrm{p}-\mathrm{CF} 3 \mathrm{C}_{6} \mathrm{H}_{4} \\
\mathrm{R}_{1}=\mathrm{R}_{2}=\mathrm{p}-\mathrm{CH}_{3} \mathrm{O} \mathrm{C}_{6} \mathrm{H}_{4} \\
\mathrm{R}_{1}=\mathrm{R}_{2}=2,2^{\prime} \text {-biphenyl }\end{array}$ & $\begin{array}{l}16 \mathrm{j} \\
16 \mathrm{k} \\
161 \\
16 \mathrm{~m} \\
16 \mathrm{n} \\
16 \mathrm{o} \\
\end{array}$ & $\begin{array}{l}\mathrm{R}_{1}=\mathrm{R}_{2}=2 \text {-pyridyl } \\
\mathrm{R}_{1}=\mathrm{R}_{2}=\mathrm{CH}_{3} \\
\mathrm{R}_{1}=\mathrm{C}_{6} \mathrm{H}_{5} \mathrm{R}_{2}=\mathrm{CH} 3 \\
\mathrm{R}_{1}=\mathrm{C}_{6} \mathrm{H}_{5} \mathrm{R}_{2}=\mathrm{H} \\
\mathrm{R}_{1}=\mathrm{R}_{2}=\text { p- } \mathrm{NH}_{2} \mathrm{C}_{6} \mathrm{H}_{4} \\
\mathrm{R}_{1}=\mathrm{H} \mathrm{R}_{2}=2 \text {-furyl }\end{array}$ \\
\hline
\end{tabular}<smiles>[R]c1cc([R])c(=O)[nH]n1</smiles><smiles>[R]c1cc2c(N)n[nH]c2nn1</smiles>

$18 \mathrm{R}^{\prime}=\mathrm{COOC}_{2} \mathrm{H}_{5}$ $19 \mathrm{R}=\mathrm{CONH} 2$ 16n $\mathrm{R}=\mathrm{C}_{6} \mathrm{H}_{5}$ $20 \mathrm{R}=2$-furyl<smiles>[R2]n1nc(N)c2c(-c3ccccc3)c(-c3ccccc3)nnc21</smiles>

17j $\mathrm{R}_{3}=\mathrm{CH}_{2} \mathrm{O}\left(\mathrm{CH}_{2}\right)_{2} \mathrm{OH}$ $17 \mathrm{j} \mathrm{R}=\left(\mathrm{CH}_{2}\right)_{2} \mathrm{O}\left(\mathrm{CH}_{2}\right)_{2} \mathrm{OH}$<smiles>[R4]c1nn([R9])c2nnc(-c3ccccc3)c(-c3ccccc3)c12</smiles>

17<smiles>CC(=O)OCCOc1nn(C2CC2)c2nnc(-c3ccccc3)c(-c3ccccc3)c12</smiles>

$21 \mathrm{X}=\mathrm{O}$ CDK1/Cyclin B: $\mathrm{IC}_{50}=8.8 \mu \mathrm{M}$

Compounds 16 were tested for their ability to inhibit in vitro the CDK1/cyclin B complex from starfish (Marthasterias glacialis) oocytes. In this assay the transfer of 33P-labeled phosphate from [33P] ATP to histone $\mathrm{H} 1$ in the absence and presence of inhibitor is measured and expressed as a percent of kinase activity without inhibitor. We also tested the cytotoxic effects against several cancer cell lines. These include human colon carcinoma (HT-29), human cervical carcinoma (HeLa), and human prostate carcinoma (PC- 3). To investigate the effect of substitution on the aromatic rings, a small number of compounds (16b-f and $16 \mathrm{~m})$ and their potency in the purified enzyme assay were measured. Compounds $16 \mathrm{c}$ and $23 \mathrm{e}$, bearing electron-withdrawing groups in the para position of both aromatic rings, were found to be inactive against CDK1/cyclin B and all the cell lines tested. In contrast, compound $16 f$, where a donor group is present in the same position, was able to inhibit the enzyme, although a 5-fold drop in potency was found, compared to the lead compound 16a. The proposed binding mode for compound 16a suggests that the aromatic ring in position 5 may display van der Waals interactions with vicinal amino acid<smiles>[X]C(NCC)Nc1n[nH]c2nnc(-c3ccco3)cc12</smiles>

$22 \mathrm{X}=\mathrm{S}$ CDK1/Cyclin B: $\mathrm{IC}_{50}>100 \mu \mathrm{M}$

residues in the enzyme. On the basis of this model, it was anticipated that derivatives $16 \mathrm{~b}$ and $16 \mathrm{~d}$, where the aromatic rings bear a bulky substituent (phenyl for $16 \mathrm{~b}$ and tert-butyl for 16d), would be significantly weaker inhibitors of CDK1. Indeed, both of them failed to inhibit CDK1 at all concentrations up to $50 \mu \mathrm{M}$. Replacement of the aromatic rings in positions 4 and 5 of the pyrazolopyridazine system in 16 a by a furan ring (16h) led to a potent $\mathrm{CDK} 1 /$ cyclin $\mathrm{B}$ inhibitor $\left(\mathrm{IC}_{50}\right) 1.5 \mu \mathrm{M}$ ), while an inactive compound (16i) was obtained when a $ð$-deficient ring was introduced. From an electrostatic point of view, this result is in accordance with the previous observation that electron-rich aromatic rings in positions 4 and 5 have a favorable effect on the inhibitory activity. The anti-CDK1 activity of $16 \mathrm{~h}$ was not accompanied by antitumor activity in the cell lines tested.

The next modifications of 16a to be examined were the elimination of one of the aromatic rings in positions 4 and 5 (16l and 16n) and the substitution of one or both of the aromatic rings by methyl groups (16j and 16k). Interestingly, only compound $16 \mathrm{n}$ maintained the activity of the lead compound against the enzyme. This 
finding suggested that the presence of an aromatic ring in position 5 of compound 16a is essential for its inhibitory activity. However, the aromatic ring in position 4 can be eliminated without resulting in a loss of activity. Again, the molecular modeling study gave us a possible explanation for this behavior. According to the proposed binding mode for compound 16a, which will be discussed later, the aromatic ring in position 5 is located in a hydrophobic pocket formed by residues Val18, Ala31, Val64, Phe80, and Ala144, while the aromatic ring in position 4 does not establish any relevant interaction. Pyrazolopyridazine $16 \mathrm{~g}$, where the connection of both phenyl groups by means of a cyclohexane ring rigidified the system, did not present inhibitory activity. This result is also in accordance with the proposed binding mode, where the phenyl groups in 16a are oriented in a parallel disposition. Obviously, the rigidification carried out in compound $16 \mathrm{~g}$ does not allow the molecule to adopt that orientation of the phenyl groups in the binding site.

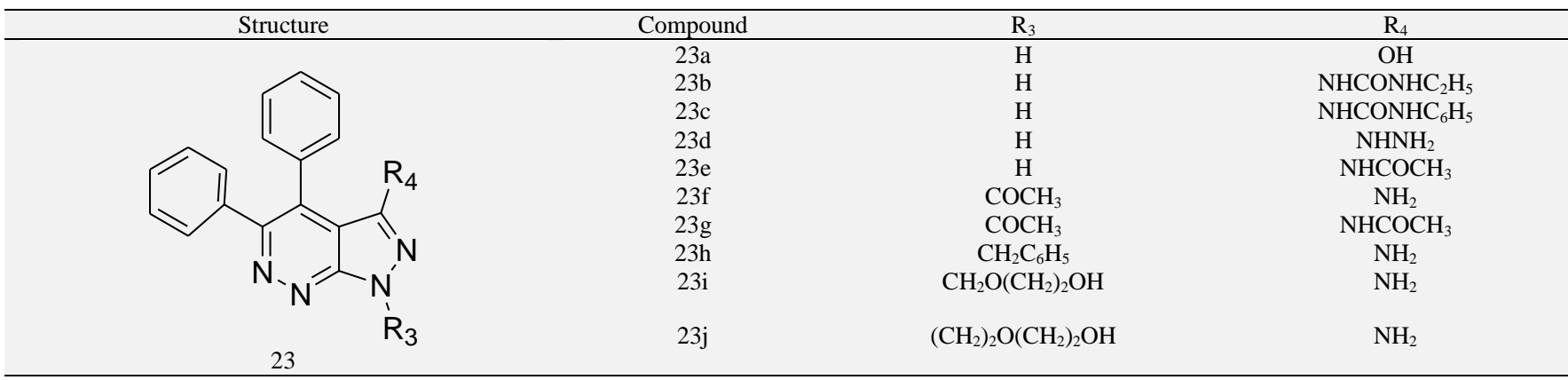

We also tested the compounds for their cytotoxic effects against several cancer cell lines. These include human colon carcinoma (HT-29), human cervical carcinoma (HeLa), and human prostate carcinoma (PC-3). The effect of substitution on the aromatic rings, a small number of compounds (16b-f and $16 \mathrm{~m}$ ) potency in the purified enzyme assay was measured. Compounds $16 \mathrm{c}$ and 16e, bearing electron-withdrawing groups in the para position of both aromatic rings, were found to be inactive against CDK1/cyclin $\mathrm{B}$ and all the cell lines tested. In contrast, compound 16f, where a donor group is present in the same position, was able to inhibit the enzyme, although a 5-fold drop in potency was found, compared to the lead compound 16a. The proposed binding mode for compound 16a suggests that the aromatic ring in position 5 may display van der Waals interactions with vicinal amino acid residues in the enzyme. On the basis of this model, it was anticipated that derivatives $16 \mathrm{~b}$ and $16 \mathrm{~d}$, where the aromatic rings bear a bulky substituent (phenyl for $16 \mathrm{~b}$ and tert-butyl for 16d), would be significantly weaker inhibitors of CDK1. Indeed, both of them failed to inhibit CDK1 at all concentrations up to $50 \mu \mathrm{M}$. Replacement of the aromatic rings in positions 4 and 5 of the pyrazolopyridazine system in 16a by a $\pi$-rich furan ring (16h) led to a potent $\mathrm{CDK} 1 /$ cyclin $\mathrm{B}$ inhibitor $\left(\mathrm{IC}_{50}\right) 1.5 \mu \mathrm{M}$ ), while an inactive compound (16i) was obtained when a $\partial$-deficient ring was introduced (Meijer et al., 2004; Brana et al., 2005). From an electrostatic point of view, this result is in accordance with the previous observation that electron-rich aromatic rings in positions 4 and 5 have a favorable effect on the inhibitory activity. The antiCDK1 activity of $16 \mathrm{~h}$ was not accompanied by antitumor activity in the cell lines tested. The next modifications of 16a to be examined were the elimination of one of the aromatic rings in positions 4 and 5 (161 and 16n) and the substitution of one or both of the aromatic rings by methyl groups ( $16 \mathrm{j}$ and $16 \mathrm{k}$ ). Interestingly, only compound 16n maintained the activity of the lead compound against the enzyme. This finding suggested that the presence of an aromatic ring in position 5 of compound 16a is essential for its inhibitory activity. However, the aromatic ring in position 4 can be eliminated without resulting in a loss of activity. Again, the molecular modeling study gave us a possible explanation for this behavior. According to the proposed binding mode for compound 16a, which will be discussed later, the aromatic ring in position 5 is located in a hydrophobic pocket formed by residues Val18, Ala31, Val64, Phe80, and Ala144, while the aromatic ring in position 4 does not establish any relevant interaction. Pyrazolopyridazine $16 \mathrm{~g}$, where the connection of both phenyl groups by means of a cyclohexane ring rigidified the system, did not present inhibitory activity. This result is also in accordance with the proposed binding mode, where the phenyl groups in 16a are oriented in a parallel disposition. Obviously, the rigidification carried out in compound $16 \mathrm{~g}$ does not allow the molecule to adopt that orientation of the phenyl groups in the binding site. Pyrazolopyridazines having more lipophilic substituents at C-3 such as acetamide $23 \mathrm{e}$ did lead to a loss of activity. By contrast, the use of other groups capable of establishing additional hydrogen bonds with the enzyme, such as ureas $23 b$ and $23 c$ and hydrazine $23 \mathrm{~d}$, maintained the inhibitory activity. Surprisingly, compound $23 \mathrm{a}$, with a hydroxyl group in the same position, proved to be inactive, while the theoretical work described later predicts a very similar orientation of compounds $16 \mathrm{a}$ and $23 \mathrm{a}$ inside the binding pocket of CDK2 (Brana et al., 2005).

Finally, compounds $23 \mathrm{f}-\mathrm{j}$ were designed to evaluate the effect of substitution in position 1 of the lead compound. Hydroxyethoxymethyl and hydroxyethoxyethyl groups present in $23 \mathrm{i}$ and $23 \mathrm{j}$, respectively, were chosen because these fragments are present in some antiviral agents, such as aciclovir, a nucleoside analogue inhibitor of the herpex simplex virus. In aciclovir, these groups mimic the carbohydrate fragment present in nucleosides. Our CDKs inhibitors were designed to occupy the ATP binding site in CDK1. Therefore, the presence of hydroxylated chains mimicking the carbohydrate fragment of ATP could increase the affinity and selectivity of the inhibitor. Unfortunately, none of derivatives (23f-j) exhibited CDK1 inhibitory or antitumor activity, demonstrating that position 1 in the pyrazolopyridazine system must be unsubstituted for CDK1 inhibition. This result is also in agreement with the modeling work carried out for these compounds and is described below, since the introduction of substituents in position 1 would prevent the electrostatic interaction with Phe. Taking into account that the most active compound tested so far is pyrazolopyridazine $16 \mathrm{~h}$ and that substitution at position 4 is not essential for activity, the next step in our SAR study was the synthesis and biological evaluation of the monofuryl 160 and their urea and thiourea derivatives and, respectively. Compounds 160 and 20 were active against CDK1 as we had expected. More interestingly, these two compounds were also active against GSK-3 with $\mathrm{IC}_{50}$ values of 0.80 and $0.66 \mu \mathrm{M}$, respectively, which enhances their potential utility in the treatment of tumoral affections. Disappointingly, the synthesized compounds did not show cytotoxic effects against the cell lines tested. This fact could be attributed to their difficulty in crossing cell membranes, even though these compounds fit the broad Lipinski guidelines, and validation of this argument will have to await the results of additional studies (Brana, et al., 2001; Ward, and Witherington. 2003). This study reveals that all compounds interact with the ATP binding pocket of the kinase. A possible explanation for this unexpected result may be that compound 23a could be interacting with the enzyme through the 4,5-diphenyl-1,2-dihydropyrazolo[3,4-c]pyridazin-3one tautomeric form (23a1). A RHF/6-31G geometry optimization of the two tautomers led to a $3.8 \mathrm{kcal} / \mathrm{mol}$ energy difference in favor of the 4,5-diphenyl-1H-pyrazolo[3,4-c]pyridazin-3-ol form 
(23a2). However, taking into account that the solvent effect was not considered, we cannot discard the possibility that compound 23a may be interacting with the enzyme's binding site through the 23a1 tautomeric form, leading to a completely different binding mode if compared to $16 \mathrm{a}$ and accounting for the lack of activity of the synthesized derivative 23a (Brana et al., 2005).

A series of pyrazolopyridazine-based CDK1 inhibitors, SAR study suggest that (i) the phenyl rings can be substituted by $\pi$-rich rings, such as furan, resulting in a 2 -fold increase of inhibition, substitution at position 4 is not relevant, while the presence of a substituent at position 5 is essential for the potency of CDK1 inhibition, the introduction of substituents at $\mathrm{N}-1$ led to a loss of activity, ethylurea, phenylurea, and hydrazine moieties in N-3 maintained the potency of inhibition. Molecular modeling studies indicate that these molecules create an interaction pattern analogous to that found in many other known small-molecule CDK inhibitors for which structural information is available. According to the proposed binding mode, 16a binds to the active site of CDK2, with the pyrazolopyridazine system in a position similar to that of the purine ring of the ATP molecule, which is the natural substrate of the enzyme but adopting a different orientation. The proposed binding model for compound 16a has allowed us to rationalize the CDK1 inhibitory activity observed for the synthesized derivatives (Brana et al., 2005).<smiles>[X]c1ccc(-c2nn([R])c(=O)c(C=N)c2-c2ccc([X])cc2)cc1</smiles>

The bromination of pyrazoline compound $24 \mathrm{a}$ was subjected to further studies. Thus, condensation of $24 \mathrm{a}$ with phydroxybenzaldehyde in absolute ethanol with a catalytic amount of ethanolic $\mathrm{KOH}$ took place at the 5-position to give 4, 5, 6trisubstituted pyridazinone (30a-c).

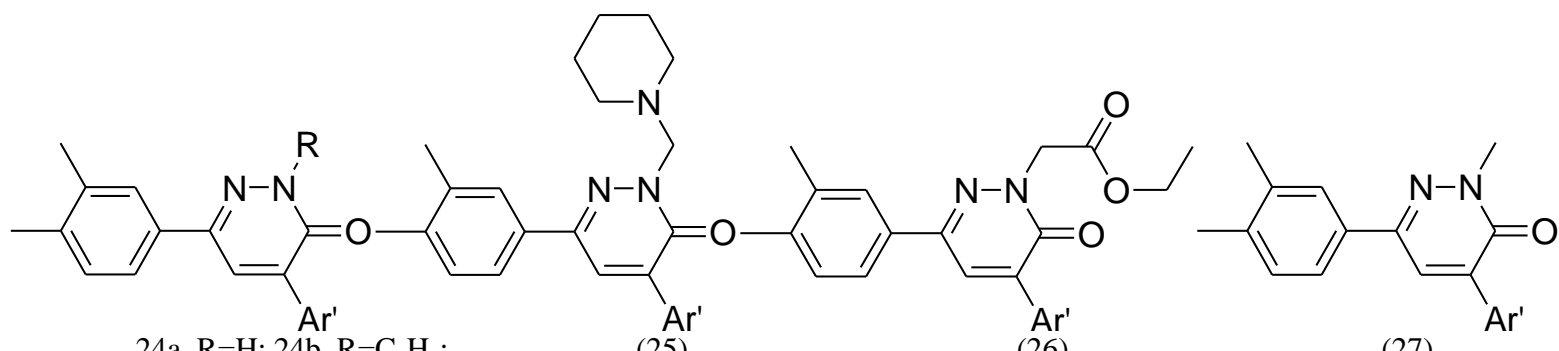

$24 \mathrm{a}, \mathrm{R}=\mathrm{H} ; 24 \mathrm{~b}, \mathrm{R}=\mathrm{C}_{6} \mathrm{H}_{5}$;<smiles>Cc1ccc(-c2cc([Al])c(=O)n(S(=O)(=O)c3ccccc3)n2)cc1-c1ccc(-c2n[nH]c(=O)c([Al])c2Br)c(C)c1</smiles>

(28)<smiles>Cc1ccc(-c2n[nH]c(=O)c(Br)c2C[Al])cc1C</smiles>

$(30 \mathrm{a}-\mathrm{c})$
Ar' $=$<smiles>Cc1c(-c2ccccc2)[nH]c2ccccc12</smiles>

$\mathrm{a}, \mathrm{Ar} "=\mathrm{C}_{6} \mathrm{H}_{4}-\mathrm{OH}(\mathrm{p}), \mathrm{b}, \mathrm{Ar} "=\mathrm{C}_{6} \mathrm{H}_{2}\left(\mathrm{OCH}_{3}\right)_{3}-3,4,5 \mathrm{c}, \mathrm{Ar} "=\mathrm{C}_{6} \mathrm{H}_{2}\left(\mathrm{OCH}_{3}\right)_{3}-2,4,6$

The behaviour of pyridazinone derivative 24 a towards electrophilic reagents like $\mathrm{POCl}_{3}$ gave 3-chloropyridazine derivative 31, by substitution of the enolic hydroxyl group with chlorine together with dehydrogenation. The resulting chloro derivative has been used as starting material for the preparation of a series of new compounds. Thus, reaction of 32 with hydrazine hydrate and/or phenylhydrazine gave the hydrazine derivatives $33 \mathrm{a}$ and $33 \mathrm{~b}$, respectively. The reaction of 31 with thiourea in absolute ethanol gave the pyridazine thione 33 , while the reaction of 31 with sodium azide in DMF gave tetrazolo pyridazine derivative 34 .<smiles>Cc1ccc(-c2cc(Br)c(=O)[nH]n2)cc1C</smiles><smiles>Cc1ccc(-c2cc(Br)c(Cl)nn2)cc1C</smiles><smiles>[R]NNc1nnc(-c2ccc(C)c(C)c2)cc1Br</smiles>

$32 \mathrm{a}, 13 \mathrm{~b}\left(\mathrm{a}, \mathrm{R}=\mathrm{H} \& \mathrm{~b}=\mathrm{C}_{6} \mathrm{H}_{5}\right)$<smiles>Cc1ccc(-c2cc(Br)c(=S)[nH]n2)cc1C</smiles><smiles>Cc1ccc(-c2cc(Br)c3nnnn3n2)cc1C</smiles> 
<smiles>Cc1ccc(-c2cc(Br)c(Nc3ccc(O)cc3)nn2)cc1C</smiles>

35<smiles>Cc1ccc(-c2cc(Br)c(Nc3ccccn3)nn2)cc1C</smiles>

36<smiles>Cc1ccc(-c2cc(Br)c(Nc3ccc(S(=O)(=O)Cc4nccs4)cc3)nn2)cc1C</smiles>

37<smiles>Cc1ccc(-c2cc(Br)c(Nc3ccc(S(=O)(=O)Cc4ncccn4)cc3)nn2)cc1C</smiles>

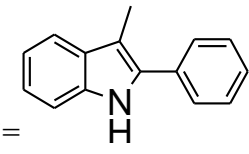

38

\section{Effect of some compounds on different types of tumor cells as cytotoxic drug}

The behaviour of compound 31 toward aromatic acid, the reaction 31 with 4-aminophenol, 2-aminopyridin, sulfathiazole and/or sulfadiazine gave the 3-substituted derivatives 35-38, respectively. The evaluation of new antiproliferative compounds as cytotoxic and anticancer agents. In recent years, novel derivatives of 1,4 dihydroindeno[1,2-b]pyrroles (39), 1H-benzo[g]indoles (40) (Pinna, et al., 2009), thieno[3,2-g]indoles (41) (Pirisi, et al., 2002), 1,4,5,6-teterahydrobenzo[6,7]cyclohepta[1,2-b]pyrroles naphto[2,3-d]imidazoles (43) (Grella, et al., 2003), pyrrole[2,3d]pyridazinones (44) (Murineddu, et al., 2002) and their cytotoxic activities in the NCI preclinical antitumor screen.<smiles>[X]c1ccccc1-n1c2ccccc2c2c(=O)[nH]ncc21</smiles>
$\mathrm{a}, \mathrm{X}=\mathrm{H}, \quad \mathrm{b}, \mathrm{X}=\mathrm{CH}_{3} \quad \mathrm{c}, \mathrm{X}=-\mathrm{CH}_{2^{-}} \quad \mathrm{d}, \mathrm{X}=-\left(\mathrm{CH}_{2}\right)_{2^{-}} \quad \mathrm{e}, \mathrm{X}=-$
$\mathrm{CH}=\mathrm{CH} \quad \mathrm{f}, \mathrm{X}=-\left(\mathrm{CH}_{2}\right)_{3^{-}}$

Novel 2,4,4a,5,6,7-hexahydro-3H-thieno[2',3':6,7]cyclohepta[1,2c]pyridazinones bearing substituted piperazine, piperidine and morpholine moieties, using a random screening approach (Silverman. 2004), and the antitumor activities of the resulting compounds $45 \mathrm{a}-1$.<smiles>[X][X]C1CCN(CN2N=C3c4cc([R])sc4CCCC3CC2=O)CC1</smiles>

Thienocyclohepta[1,2-c]pyridazinones 45a-1.

$45 \mathrm{a}, \mathrm{R}=\mathrm{H}, \mathrm{X}=\mathrm{N}, \mathrm{Y}=\mathrm{Ph}$ $45 \mathrm{~b}, \mathrm{R}=\mathrm{H}, \mathrm{X}=\mathrm{N}, \mathrm{Y}=\mathrm{O}-\mathrm{OCH}_{3}-\mathrm{Ph}$

$45 \mathrm{c}, \mathrm{R}=\mathrm{H}, \mathrm{X}=\mathrm{N}, \mathrm{Y}=\mathrm{o}-\mathrm{F}-\mathrm{Ph}$

$45 \mathrm{~d}, \mathrm{R}=\mathrm{H}, \mathrm{X}=\mathrm{N}, \mathrm{Y}=\mathrm{CH}_{3}$ $45 \mathrm{e}, \mathrm{R}=\mathrm{CH}_{3}, \mathrm{X}=\mathrm{N}, \mathrm{Y}=\mathrm{Ph} \quad 45 \mathrm{f}$

$\mathrm{R}=\mathrm{CH}_{3}, \mathrm{X}=\mathrm{N}, \mathrm{Y}=\mathrm{O}-\mathrm{OCH}_{3}-\mathrm{Ph}$

$45 \mathrm{~g}, \mathrm{R}=\mathrm{CH}_{3}, \mathrm{X}=\mathrm{N}, \mathrm{Y}=\mathrm{o}-\mathrm{F}-\mathrm{Ph} 45 \mathrm{~h}, \mathrm{R}=\mathrm{CH}_{3}, \mathrm{X}=\mathrm{N}, \mathrm{Y}=\mathrm{CH}_{3} \quad 45 \mathrm{i}$, $\mathrm{R}=\mathrm{H}, \mathrm{X}=\mathrm{CH}_{2}, \mathrm{Y}=\mathrm{CH}_{3}$

$45 \mathrm{j}, \quad \mathrm{R}=\mathrm{CH}_{3}, \quad \mathrm{X}=\mathrm{CH}_{2}, \quad \mathrm{Y}=\mathrm{CH}_{3}$ $451, \mathrm{R}=\mathrm{CH}_{3}, \mathrm{X}=\mathrm{O}$
A series of twelve substituted pyridazinones $45 \mathrm{a}-1$, and eight of them $(45 \mathrm{c}-\mathrm{e}, \mathrm{h}-1)$ were evaluated at a single concentration of $10^{-5}$ $\mathrm{M}(10 \mu \mathrm{M})$ for their antitumor activities. The primary screening was tested to determine their growth inhibitory properties against sixty different human tumor cell lines in vitro (Monks, et al., 1991; Paull, et al., 1989; Boyd, and Paull. 1995). The compounds were added at a single concentration and the cell culture was incubated for $48 \mathrm{~h}$. End point determinations were made using a protein binding dye, sulforhodamine B (SRB), which was used to estimate cell viability or growth (Boyd. 1997). All compounds have demonstrated being scarcely active or completely inactive in the antitumor screening in vitro. 5-Fluorouracil (5-FU) was used as reference compound with the mean growth inhibitory effect (GI50) of $2.45 \times 10^{-5} \mathrm{M}$ (Block, and Beale. 2004). Nevertheless, compounds $45 \mathrm{~d}$ and $45 \mathrm{~h}$ displayed a higher anti-proliferative activity in the non-small cell lung cancer cell line EKVX and in the CNS cancer cell line SNB-75, which showed growth inhibitions of $27.94 \%$ and $27.86 \%$, respectively. Compounds $45 \mathrm{k}$ and 451 also showed cell growth inhibitory activity, even if weaker than the one expressed by $45 \mathrm{~d}$ and $45 \mathrm{~h}$. In particular, compound 451 was found to be active as growth \% inhibitor of the leukemia cell line RPMI- 8226 with a value of $24.95 \%$; the derivative $45 \mathrm{k}$ was active on leukemia cell line SR with a value of $24.83 \%$ and non-small cell lung cancer cell line EKVX with a value of $23.93 \%$. Moreover, $7 \mathrm{e}$ was found to be active as growth \% inhibitor of the nonsmall cell lung cancer cell line EKVX with a value of $21.09 \%$. Finally, $45 \mathrm{c}$ and $45 \mathrm{i}$ showed a growth $\%$ inhibitor of non-small cell lung cancer cell line HOP-92 with values of 18.97, and $19.80 \%$, respectively (Abd El-Ghaffar et al., 2011).

The most prominent distinctions between healthy and cancerous cells are the different energy and nutritional needs associated with the rapid proliferation of cancer cells (Devita, et al., 2005). The cancer cells maintain a different metabolic state relative to normal cells. In normal cells, glucose is metabolized by glycolysis and oxidative phosphorylation when oxygen is available. Glycolysis converts glucose into two equivalents of pyruvate. Further metabolism by oxidative phosphorylation involves the conversion of pyruvate to acetyl-CoA and entry into the Krebs cycle with the potential of generating additional ATP. In cancer cells this process is altered and much of the pyruvate derived from glucose is instead converted to lactic acid even in aerobic conditions. The mechanism(s) that drive this altered metabolism in cancer cells are not fully understood. However, is the differential expression of two isozymes of pyruvate kinase (PK)? Alternative RNA splicing yield the M1 and M2 forms of pyruvate kinase (PKM1 and PKM2). PKM2 is widely expressed in undifferentiated embryonic tissues and during development many differentiated tissues switch to express PKM1. A second gene produces two additional PK isozymes based on alternative splicing events to produce PKL and PKR which are expressed in specific adult tissues. An important 
realization in cancer biology was the recognition that all cancer cells express the PKM2 isozyme (Jiang et al., 2010). The expression of PKM2 in cancer cells has been described as a clinical marker of malignancy for some time. Pyruvate kinase catalyzes the transformation of phosphoenolpyruvate (PEP) and ADP to pyruvate and ATP when the enzyme exists as a homotetramer (dimer of dimers). Three PK isozymes (PKM2, PKL and PKR) require the binding of fructose-1, 6-bis-phosphate (FBP) at an allosteric site in the tetrameric complex for activity. In contrast, PKM1 does not require allosteric activation by FBP binding and retains a high affinity for PEP and high catalytic rate in its native state. Importantly, in cancer cells PKM2 exists as a less active dimer with little affinity for PEP and a low catalytic rate. It is theorized that down-regulation of the final step of glycolysis is a functional reason for the expression of PKM2 in cancer cells. Many glycolytic intermediates are starting points for amino acid, nucleic acid and lipid biosynthesis. Decreased pyruvate kinase activity is hypothesized to facilitate the shunting of glycolytic intermediates into these anabolic pathways required for cell growth. Hence, the expression of the less active PKM2 isozyme in cancer cells may enable anabolic processes necessary for cancer cell proliferation. PKM1 expressing cells have a diminished capacity for tumor development in vivo relative to PKM2 expressing cells. One unique property that appears to give PKM2 expressing cells this proliferative advantage is that PKM2 is a phosphotyrosine binding protein. In cancer cells there is a general up-regulation of signalling events through the actions of protein kinases resulting in an elevated state of phosphorylated proteins relative to normal differentiated cells. It has been demonstrated that the binding of phosphorylated peptides to PKM2 is accompanied by the release of FBP and the further down-regulation of this enzyme. This down-regulation exacerbates the shift away from the catalytic levels associated with PKM1 and toward an anabolic state providing the needed resources for rapid proliferation (Devita, et al., 2005; Staal, and Rijksen.1991).

The expression of PKM2 in cancer cells provides an attractive target for cancer therapy. Further, the observed down-regulation of PKM2 activity in cancer cells relative to the high PKM1 activity present in many normal cells suggests a therapeutic strategy whereby activation of PKM2 may restore normal cellular metabolism and, consequently, decreased cellular proliferation. To examine this possibility, developed small molecule activators of PKM2 based upon a bis-sulfonamide scaffold 20 and the substituted thieno [3, 2-b] pyrrole[3,2-d]pyridazinones. The development of the luminescent assay detection system for protein kinases and screening details were previously presented. Akin to our earlier report, to assess the activity of the compounds described here we utilized orthogonal assays that respond to ATP or pyruvate generation by PKM2 through measurement of either firefly luciferase activity or lactate dehydrogenase (LDH) activity, respectively. A quantitative high-throughput screen (qHTS) of nearly 300,000 small molecules of the NIH Molecular Libraries Small Molecule Repository was performed utilizing the firefly luciferase assay system. Numerous small molecule activators of PKM2 were identified. We ultimately selected two chemotypes for advanced interrogation. These agents are represented by the substituted thieno[3,2-b]pyrrole[3, 2-d] pyridazinone 46 and substituted $\mathrm{N}, \mathrm{N}^{\prime}$ diaryl sulfonamide 47. The report detailing NCGC00030335 (47), it was essential to establish the cooperative nature of these agents with the native substrates of PKM2. Given the allosteric activation of PKM2 by FBP, it was desirable to examine how our lead chemotypes affected the steady-state kinetics of PEP and ADP. In the absence of activator, hPK shows low affinity for PEP (KM 1.5 mM). In the presence of NCGC00031955 (46) or FBP, the KM for PEP decreased 10 -fold to $0.13 \pm 0.04 \mathrm{mM}$ or $0.1 \pm 0.02$ $\mathrm{mM}$, respectively with lesser effects on Vmax (values of 245 pmols/min with or without FBP and 255 pmols/min with or without NCGC00031955). In contrast, variation of the concentration of ADP in the presence and absence of activators shows that the steady-state kinetics are not significantly affected (KM for ADP = $0.1 \mathrm{mM}$ in either condition). Thus, NCGC00031955 (46) activates
PKM2 by increasing the enzyme's affinity for PEP and has little effect on ADP kinetics. This is similar to what we observed for FBP which agrees with previous reports demonstrating increased affinity for PEP as the reason for activation of PKM2 by FBP.

Nitration of the ethyl $4 \mathrm{H}$-thieno [3, 2-b] pyrrole-5-carboxylate intermediate occurred on the 6-position of the pyrrole ring. Reduction of the nitro group and the pyrimidinone ring was formed upon condensation with ammonia formate and formamide at elevated temperatures. The benzylation of the amide nitrogen occurred under similar conditions as previously described. As a standard practice, NCGC00031955 (46) was re-synthesized and found to possess an AC50 value of $63 \mathrm{nM}$ and maximum response of $122 \%$ in the ATP generation assay system and also showed good potency and efficacy in the LDH coupled reaction (AC50 value of 326 $\mathrm{nM}$, maximum response of $224 \%$ ). Our first SAR evaluations involved changes directly to the heterocyclic core structure while retaining the standard 2-fluorobenzyl substitution from the pyridazinone ring amide. Steric expansions of the methyl group at the 2-position of the thiophene ring were typically well tolerated [for instance the ethyl and isopropyl analogues $48\left(\mathrm{AC}_{50}=100 \mathrm{nM}\right.$, maximum response $=105 \%)$ and $49($ AC50 $=142 \mathrm{nM}$, maximum response $=106 \%)$ ]. In general, comparable potencies for these compounds were observed in the LDH assay, yet the efficacies were typically 2-3 folds higher (this was a general trend for all analogues). Removal of the methyl group resulted in a loss of potency and efficacy $[50(\mathrm{AC} 50=605 \mathrm{nM}$, maximum response $=$ 93\%)]. Insertions of heteroatoms (including oxygen and sulfur) typically resulted in improved potency including SMe [52 (AC50 $=24 \mathrm{nM}$, maximum response $=96 \%)]$ and $\mathrm{S}(\mathrm{O}) \mathrm{Me}[53(\mathrm{AC50}=$ $25 \mathrm{nM}$, maximum response $=98 \%$ )] .

Interestingly, oxidation past the sulfoxide to the sulfone resulted in a completely inactive analogue. Carbonyls and alcohols were examined and found to retain good potencies and maximum responses [for instance $59(\mathrm{AC} 50=16 \mathrm{nM}$, maximum response $=$ $100 \%), 60(\mathrm{AC} 50=48 \mathrm{nM}$, maximum response $=103 \%)$ and 61 $(\mathrm{AC} 50=11 \mathrm{nM}$, maximum response $=108 \%)]$. In stark contrast to substitutions on the 2-position of the thiophene ring, the methyl group on the pyrrole ring nitrogen was found to be an absolute necessity. Alterations from the methyl to the ethyl and isopropyl groups were ineffective and lack of substitution resulted in an inactive analogue as well. Further, amides and sulfonamides were examined and were not tolerated (data not shown). Addition of a methyl group to the 6 position of the pyridazinone ring was also not allowed [67 (AC50 > 30 $\mu \mathrm{M}$, maximum response <80\%)]. Alteration from the pyridazinone to a pyrimidinone ring system was additionally problematic [68 (AC50 > $35 \mu \mathrm{M}$, maximum response $<80 \%$ )]. The necessity of the benzyl substituent was proven through examination of the corresponding phenyl analogue 69 and the n-pentyl analogue 70, both of which had marked loss of potency. Following the examination of the core heterocycle and selected appendages, a phenyl ring scan on the benzyl substituent was performed. The results suggest a less focused SAR for this moiety; however, selected trends did exist. For instance, bulky substituents were typically not successful at the para position of the ring [for instance $76(\mathrm{AC} 50=326 \mathrm{nM}$, maximum response $=$ $91 \%), 78($ AC50 $=553 \mathrm{nM}$, maximum response $<80 \%)$ and 88 (AC50 > $15 \mu \mathrm{M}$, maximum response <80\%)]. Electron withdrawing substitutions were typically favored [for instance 80 (AC50 = $44 \mathrm{nM}$, maximum response $=96 \%), 81($ AC50 $=49 \mathrm{nM}$, maximum response $=94 \%)$ ], however examples such as the 4methoxybenzyl analogue 79 were exceptions $($ AC50 $=37 \mathrm{nM}$, maximum response $=96 \%$ ). With a better idea of the SAR for this chemotype, we next considered the aqueous solubility of these agents. Several of the most potent analogues were profiled by a commercial provider 35 of solubility and it was determined that nearly all compounds examined had aqueous solubility levels (measured in both $\mu \mathrm{g} / \mathrm{mL}$ and $\mu \mathrm{M}$ ) below detectable limits. One of the few exceptions was the sulfoxide analogue 53 which had an aqueous solubility of $4.4 \mu \mathrm{g} / \mathrm{mL}$. To expand upon this result, we synthesized numerous phenyl ring analogues that maintained the key sulfoxide moiety. We choose to expand our phenyl ring scan 
to include aniline and phenol derivatives in hopes of gaining additional solubility (Jiang et al., 2010).

Additionally, several of these agents possessed improved aqueous solubility including $90($ AC50 $=73 \mathrm{nM}$, maximum response $=99 \%$, aqueous solubility $=37.4 \mu \mathrm{g} / \mathrm{mL}), 91(\mathrm{AC} 50=92 \mathrm{nM}$, maximum response $=93 \%$, aqueous solubility $=29.6 \mu \mathrm{g} / \mathrm{mL})$ and $92($ AC50 $=$ $130 \mathrm{nM}$, maximum response $=102 \%$, aqueous solubility $=16.9$ $\mu \mathrm{g} / \mathrm{mL}$ ). With the SAR and solubility assessments established, it was essential to consider the selectivity of these compounds versus PKM1, PKR and PKL. The $\mathrm{N}, \mathrm{N}^{\prime}$-diarylsulfonamide chemotype presented in our previous manuscript possessed a high degree of selectivity for activation of PKM2. Gratifyingly, the substituted thieno[3,2-b]pyrrole[3,2-d]pyridazinones presented here were equally selective for PKM2 activation versus PKM1. Further, all analogues examined were inactive versus PKL and PKR (AIDs 1541, 1542, 1543, 1780, 1781, and 1782). Warburg's finding that cancer cells show altered cellular respiration and metabolism ranks as one of the earliest observations in cancer biology. A key realization associated with the Warburg effect is the reexpression of PKM2 in all cancer cells leading to increased availability of glycolytic intermediates for biosynthesis of the amino acid, nucleic acid and lipid building blocks of cellular construction. The native, down-regulated kinetics of PKM2 in combination with the allosteric control of PKM2 activity by FBP and binding to phosphotyrosine proteins is an important aspect of the altered metabolic state of cancer cells. Activation of PKM2 to levels comparable to PKM1 represents an intriguing potential strategy to halt the proliferative state of cancer cells by shuttling the required glycolytic intermediates/cellular building blocks away from an anabolic state of metabolism. Here we describe a novel chemotype based upon substituted thieno[3,2-b]pyrrole[3,2-d]pyridazinone scaffold for the activation of PKM2. This agent was expanded upon via chemical synthesis and numerous SAR aspects were explored. These agents were found to increase the affinity of PKM2 for phosphoenolpyruvate (PEP) and were capable of activation responses beyond that achieved by the native allosteric activator FBP. Several agents were found with potencies below $100 \mathrm{nM}$ and maximum responses $\geq$ FBPmediated activation and appropriate aqueous solubility including 90, 91 and 92. Explorations of these agents selectivity revealed that the thieno[3,2b]pyrrole[3,2-d]pyridazinone chemotype was selective for PKM2 with little or no activity versus PKM1, PKL and PKR. These novel activators of PKM2 provide the necessary tool compounds to explore the hypothesis that PKM2 activation will ameliorate the Warburg effect, and thereby decrease cancer cell proliferation (Jiang et al., 2010).<smiles>Cc1cc2c(s1)c1cnn(Cc3ccccc3F)c(=O)c1n2C</smiles>

Structures of the two lead activators of PKM2 substituted thieno [3, 2-b] pyrrole[3, 2-d] pyridazinone NCGC00031955 (46).<smiles>[R]c1cc2c(s1)c1cnn(-c3ccccc3)c(=O)c1n2[R2]</smiles>

69<smiles>[R]C(C)c1cc2c(s1)c1cnn(Cc3ccccc3F)c(=O)c1n2C</smiles>

$48(\mathrm{R}=\mathrm{H}), 49\left(\mathrm{R}-\mathrm{CH}_{3}\right) 60(\mathrm{R}=\mathrm{n}-$ pentyl $)$

71-89 (R=substituted benzyl)

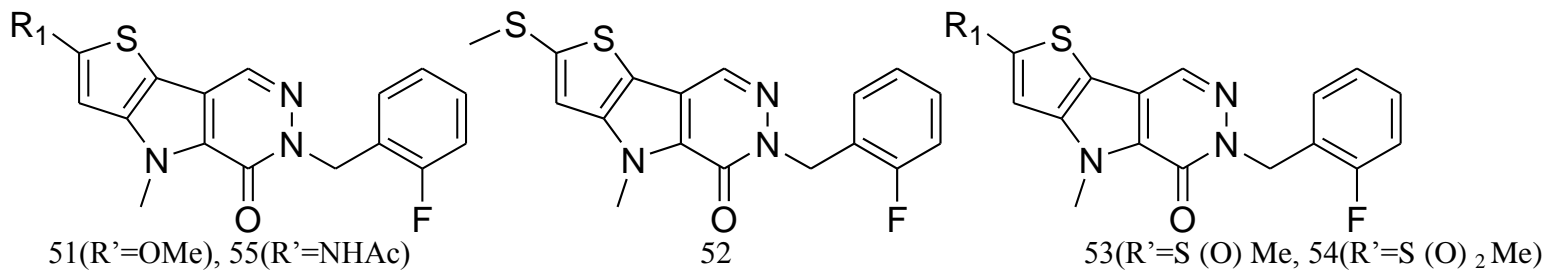

$57\left(\mathrm{R}^{\prime}=\mathrm{CN}\right), 58\left(\mathrm{R}^{\prime}=\mathrm{COOMe}\right)$<smiles>Cn1c2ccsc2c2cnn(Cc3ccccc3F)c(=O)c21</smiles>

50<smiles>Cc1cc2c(s1)c1c(C)nn(Cc3ccccc3F)c(=O)c1n2C</smiles>

67<smiles>Cn1c2cc([N+](=O)[O-])sc2c2cnn(Cc3ccccc3F)c(=O)c21</smiles><smiles>Cn1c2ccsc2c2cnn(Cc3ccccc3F)c(=O)c21</smiles>

68<smiles>Cn1c2cc(CO)sc2c2cnn(Cc3ccccc3F)c(=O)c21</smiles>

59<smiles></smiles>

$46,49-70$ 
<smiles>Cn1c2cc(Br)sc2c2cnn(Cc3ccccc3F)c(=O)c21</smiles>

$61\left(\mathrm{R}_{1}=\mathrm{B}(\mathrm{OH})_{2}, 62\left(\mathrm{R}_{1}=\mathrm{COMe}\right)\right.$<smiles>Cn1c2cc(Br)sc2c2cnn(Cc3ccccc3F)c(=O)c21</smiles>

53<smiles>[R]C(=C)c1cc2c(s1)c1cnn(Cc3ccccc3F)c(=O)c1n2C</smiles>

$63\left(\mathrm{R}_{1}=\mathrm{CHOH}(\mathrm{Me})\right)$

Selected thieno[3,2-b]pyrrole[3,2-d]pyridazinones and thieno[3,2-b]pyrrole[3,2-d]pyrimidinones<smiles>[R]c1cc2c(s1)c1ncn(-c3ccccc3F)c(=O)c1n2C</smiles>

$(46,48-63)$

$\mathrm{R}=\mathrm{Me}$, Et, iPr, H, OMe, SME, S (O) Me, $\mathrm{S}\left(\mathrm{O}_{2}\right) \mathrm{Me}, \mathrm{NO}_{2}$, NHAc, CN, COOMe, $\mathrm{CHO}, \mathrm{CH}_{2} \mathrm{OH}, \mathrm{B}(\mathrm{OH})_{2}, \mathrm{COMe}, \mathrm{CHOHMe}$<smiles>[R]n1c2cc(C)sc2c2ncn(-c3ccccc3F)c(=O)c21</smiles>

(64-66) R= H, Et, iPr<smiles>Cc1cc2c(s1)c1nc(C)n(-c3ccccc3F)c(=O)c1n2C</smiles>

(67)<smiles>Cn1c2ccsc2c2nnn(-c3ccccc3F)c(=O)c21</smiles>

(68)<smiles>[R]n1cnc2c3sc(C)cc3n(C)c2c1=O</smiles>

$(69,70) \mathrm{R}=\mathrm{n}$-phenyl, n-pentyl<smiles>COc1ccc(S(=O)(=O)N2CCN(S(=O)(=O)c3ccc4c(c3)OCCO4)CC2)cc1</smiles><smiles>[R3]n1ncc2c3sc(C)cc3n(C)c2c1=O</smiles>

$46,71-89$

\begin{tabular}{cccccc}
\hline S.No & $\mathrm{R}^{3}$ & S.No & $\mathrm{R}^{3}$ & S.No & $\mathrm{R}^{3}$ \\
\hline 46 & 2-flourobenzyl & 77 & 4-methylbenzyl & 84 & 2,3,4-triflourobenzyl \\
71 & Benzyl & 78 & 4-triflouromethylbenzyl & 85 & 2,3,5,6-tetraflourobenzyl \\
72 & 3-flourobenzyl & 79 & 4-methoxybenzyl & 86 & 2-flouro-3-methylbenzyl \\
73 & 4-flourobenzyl & 80 & 2,4-diflourobenzyl & 87 & 2-flouro-4-methylbenzyl \\
74 & 2-chlorobenzyl & 81 & 2,6-diflourobenzyl & 88 & 2-flouro-4-triflouromethylbenzyl \\
75 & 3-chlorobenzyl & 82 & 2,3-diflourobenzyl & 89 & 3-flouro-3-methoxylbenzyl \\
76 & 4-chlorobenzyl & 83 & 2-chloro-6-flourobenzyl & & \\
\hline
\end{tabular}

Selected thieno [3, 2-b] pyrrole[3, 2-d] pyridazinones<smiles>[R5]c1cc2c(s1)c1cnn(C)c(=O)c1n2C</smiles>

$46,53,90-92$

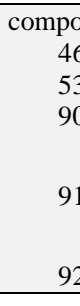

pounds

46
53

90

91

92
R1

$-\mathrm{CH}_{3}$

$-\mathrm{S}(\mathrm{O}) \mathrm{CH}_{3}$

$-\mathrm{S}(\mathrm{O}) \mathrm{CH}_{3}$

$-\mathrm{S}(\mathrm{O}) \mathrm{CH}_{3}$

$-\mathrm{S}(\mathrm{O}) \mathrm{CH}_{3}$

\section{R3}

2-flourobenzyl

2-flourobenzyl

3-methoxybenzyl

3-(methyl)aniline

3-(methyl)phenol
In continuation of an ongoing program aiming at finding new structure leads with potential chemotherapeutic activities it was thought worthwhile to synthesize and investigate the antitumor activity of some novel pyridazinone derivatives comprising the 
benzenesulfonamide moiety (93a-h). Only five representative compounds 93a, 93b, 93d, 93g and 93h were selected and granted NSC codes Viz; NSC 749115, NSC 749114, NSC 747557, NSC 749116 and NSC 747558 respectively and screened at NCI for antiproliferative activity at a single high dose $\left(10^{-5} \mathrm{M}\right)$ in full 60 cell panel. Compound (93h) NSC 747558 exhibited the best result at a single dose and was selected for further evaluation at five dose level screening. It showed remarkable antiproliferative activity at five dose level screening and was referred to Biological Evaluation Committee of NCI for advanced study. The novel compounds (93a-h) and in vitro anticancer efficacy against human cancer cell lines of 93a, 93b, 93d, 93g and 93h compounds (Rathishet al., 2012). Pyridazinone derivatives bearing a benzenesulfonamide moiety (93a-h), one of these derivatives (93h) had excellent in vitro anticancer activity and can be used as lead compound for developing new anticancer agents (Rathishet al., 2012).<smiles>[R]c1ccc(-c2ccc(=O)n(-c3ccc(S(N)(=O)=O)cc3)n2)c([R])c1[R]</smiles>

93a-h

93a $R_{1}=R_{2}=R_{3}=H$, 93b $R_{1}=R_{2}=R_{3}=C l, 93$ c $R_{1}=R_{2}=R_{3}=C_{3}$, 93d $\mathrm{R}_{1}=\mathrm{R}_{2}=\mathrm{R}_{3}=\mathrm{CH}_{3} \mathrm{O}$

93e $\quad \mathrm{R}_{1}=\mathrm{R}_{2}=\mathrm{CH}_{3}, \quad \mathrm{R}_{3}=\mathrm{Cl} \quad$ 93f $\quad \mathrm{R}_{1}=\mathrm{CH}_{3}, \quad \mathrm{R}_{2}=\mathrm{H}, \quad \mathrm{R}_{3}=\mathrm{CH}_{3}$, $93 \mathrm{gR}_{1}=\mathrm{R}_{2}=\mathrm{R}_{3}=$ Biphenyl,

93h $\mathrm{R}_{1}=\mathrm{R}_{2}=\mathrm{R}_{3}=\mathrm{C}_{2} \mathrm{H}_{5}$

6-aryl-2-benzenesulfonamide-pyridazinones (93a-h)

Various pyridazinone derivatives were assessed for their anticancer activity. It was found that all new eight compounds tested showed weak or incomplete activity without significant differences between 9-substituted and unsubstituted derivatives. Specifically, two of them showed scant activity, while others showed no activity in the cell growth inhibition assay against sixty different human cancer cell lines panel in vitro. The effective molecules for anti-proliferative activity, specifically in non-small cell lung cancer and CNS cancer respectively, so they might be useful as leads for designing new compounds with potential antitumoral activity. The necessity for further investigations to clarify the molecular mechanisms involved in antitumor activities to acquire more information about the structural requirements for enhancing anticancer activities and minimizing neurotoxicities (Rathishet al., 2012)

\section{Conclusion}

Synthesis of more new derivatives with different substituent at different positions is needed. Further investigations will be required for a more detailed evaluation of anticancer pyridazine compounds with different molecular mechanisms for enhancing anticancer activities and minimizing toxicities.

\section{References}

[1] Abd El-Ghaffar NF, Mohamed MK, Kadah MS, Radwan AM, Said GH, Abdel Al SN (2011) Synthesis and anti-tumor activities of some new pyridazinones containing the 2-phenyl-1H-indolyl moiety. J Chem Pharm Res 3(3): 248-259.

[2] Abdelrazek FM, Michael FA, Mohamed AE. (2006) Synthesis and molluscicidal activity of some 1,3,4-triaryl-5-chloropyrazole, pyrano[2,3-c]pyrazole, pyrazolylphthalazine and pyrano[2,3 d]thiazole derivatives. Arch Pharm (Weinheim) 339(6): 305-12. http://dx.doi.org/10.1002/ardp.200500259.

[3] Akinaga S, Sugiyama K, Akiyama, T (2000) UCN-01 (7Hydroxystaurosporine) and Other Indolocarbazole Compounds: A New Generation of Anti-Cancer Agents for the New Century? AntiCancer Drug Des 15: 43-52.

[4] Allerton CM, Andrews MD, Blagg J, Ellis D, Evrard E, Green MP, Liu KK, McMurray G, Ralph M, Sanderson V, Ward R, Watson L
(2009) Design and synthesis of pyridazinone-based 5-HT(2C) agonists. Bioorg Med Chem Lett 19(19): 5791-5. http://dx.doi.org/10.1016/j.bmcl.2009.07.136.

[5] Asif M (2012). Some Recent Approaches of Biologically Active Substituted Pyridazine and Phthalazine Drugs. Curr Med Chem 19(18): 2984-2991. http://dx.doi.org/10.2174/092986712800672139.

[6] Asif M, Singh A (2010) Exploring Potential, Synthetic Methods and General Chemistry of Pyridazine and Pyridazinone: A Brief Introduction. Inter J Chem Tech Res 2(2): 1112-1128.

[7] Bansal R, Kumar D, Carron R, de la Calle C (2009)Synthesis and vasodilatory activity of some amide derivatives of 6-(4carboxymethyloxyphenyl)-4,5-dihydro-3(2H)-pyridazinone. Eur J Med Chem 44(11): 4441-7. http://dx.doi.org/10.1016/j.ejmech.2009.06.006.

[8] Bashir R, Yaseen S, Ovais S, Ahmad S, Hamid H, Alam MS, Samim M, Javed K. (2010) Synthesis and biological evaluation of some novel sulfamoylphenyl-pyridazinone as anti-inflammatory agents (Part-I). J Enz Inhib \& Med Chem 25(2): 266-271.

[9] Batra JJK, Powers LJ, Hess FD, Hamel E (1986) Derivatives of 5,6Diphenylpyridazin-3-one: Synthetic Antimitotic Agents Which Interact with Plant and Mammalian Tubulin at a New Drug-bindingSite. Cancer Research, 46: 1889-1893.

[10]Batra JK, Jurd, L, Hamel, E. (1985) Structure-function studies with deriva tives or6-benzyl-1,3-benzodioxole, a new class of synthetic compounds which inhibit tubulin polymerization and mitosis. Mol Pharmacol 27: 94-102.

[11]Block HJ, Beale JM (2004) Wilson and Gisvold's Textbook of Organic Medicinal and Pharmaceutical chemistry, 11th ed.; Lippincott Williams \& Wilkins: Baltimore, MD, USA, 390-394.

[12]Boyd MR (1997) In Cancer Drug Discovery and Development; Teicher, B.A., Ed.; Humana Press: Totowa, NJ, USA, 2: 23-43.

[13]Boyd MR, Paull KD (1995) some practical considerations and applications of the national cancer institute in vitro anticancer drug discovery screen. Drug Dev Res, 34: 91-109. http://dx.doi.org/10.1002/ddr.430340203.

[14]Brana MF, Anorbe L, Tarrason G, Mitjans F, Piulats J (2001) Synthesis and Biological Evaluation of Novel Bisindolylmaleimides That Inhibit Vascular Endothelial Cell Proliferation. Bioorg Med Chem 11: 2701-2703. http://dx.doi.org/10.1016/S0960-894X (01)00535-2.

[15]Brana MF, Cacho M, Garcia ML, Mayoral EP, Lopez B, de PascualTeresa B, Ramos A, Acero N, Llinares F, Munoz-Mingarro D, Lozach O, Meijer L (2005). Pyrazolo[3,4-c]pyridazines as Novel and Selective Inhibitors of Cyclin-Dependent Kinases. J Med Chem 48: 6843 6854. http://dx.doi.org/10.1021/jm058013g

[16]Buchman R, Scozzie J A, Ariyan ZS, Heilman RD, Rippin DJ, Pyne WJ, Powers LJ (1980) Antihypertensive 5,6-diarylpyridazin-3-ones. J Med Chem 23: 1398-1405. http://dx.doi.org/10.1021/jm00186a021.

[17]Chabner BA, Amrein PC, Druker BJ, Michaelson MD, Mitsiades CS, Goss PE, Ryan DP, Ramachandra S, Richardson PG, Supko JG, Wilson WH (2005) Antineoplastic Agents. In Goodman \& Gilman's the Pharmacological Basis of Therapeutics, 11th ed.; Brunton, L.L., Lazo, J.S., Parker, K.L., Eds.; Mc Graw-Hill Professional: New York, NY, USA, pp. 1315-1403.

[18]Cignarella G, Barlocco D, Curzu MM, Pinna GA, Cazzulani P, Cassin M, Lumachi B (1990) Synthesis and pharmacological evaluation of 4,4a-dihydro-5H-[1]benzopyrano[4,3-c]pyridazin-3(2H)-ones bioisosters of antihypertensive and antithrombotic benzo[H]cinnolinones. Eur J Med Chem 25: 749-756. http://dx.doi.org/10.1016/0223-5234 (90)90194-8.

[19]Cignarella G, Barlocco D, Pinna GA, Loriga M, Curzu MM, Tofanetti O, Germini M, Cazzulani P, Cavalletti E (1989) Synthesis and biological evaluation of substituted benzo[H]cinnolinones and $3 \mathrm{H}$ benzo[6,7]cyclohepta[1,2-c]pyridazinones: higher homologues of the antihypertensive and antithrombotic $5 \mathrm{H}$-indeno[1,2-c]pyridazinones. J Med Chem 32: 2277-2282. http://dx.doi.org/10.1021/jm00130a009.

[20]Costantino L, Rastelli G, Vescovini K, Cignarella G, Vianello P, Corso AD, Cappiello M, Mura U, Barlocco D (1996) Synthesis, activity, and molecular modeling of a new series of tricyclic pyridazinones as selective aldose reductase inhibitors. J Med Chem 39 4396-4405. http://dx.doi.org/10.1021/jm960124f.

[21]Costas T, Besada P, Piras A, Acevedo L, Ya-ez M, Orallo F, Laguna R, Terán C (2010) New pyridazinone derivatives with vasorelaxant and platelet antiaggregatory activities. Bioorg \& Med Chem Lett, 20(22): 6624-6627. http://dx.doi.org/10.1016/j.bmcl.2010.09.031.

[22]Costas T, Besada P, Piras A, Acevedo L, Ya-ez M, Orallo F, Laguna R, Terán C (2010) New pyridazinone derivatives with vasorelaxant and platelet antiaggregatory activities. Bioorg \& Med Chem Lett, 20(22): 6624-6627. http://dx.doi.org/10.1016/j.bmcl.2010.09.031. 
[23]Devita VT Jr, Hellman S, Rosenberg SA, editors (2005) Cancer Principles \& Practice of Oncology. 7. Lippincott Williams \& Wilkins Philadelphia.

[24]Faidallah HM, Khan KA, Makki MSI (2011). Synthesis and Biological Evaluation of New Fused Isoxazolo[4,5-d] Pyridazine Derivatives. J Chinese Chem Soc 58: 191-198. http://dx.doi.org/10.1002/jccs.201190076.

[25]Fidesser E, Haider N, Jbara R (2001) Convenient Synthesis of New 3 Aminocarbazole and Pyrimido[5,4-b]carbazole Derivatives. ARKIVOC, 2: 133-139.

[26]Fidler IJ (2003). The pathogenesis of cancer metastasis: the 'seed and soil' hypothesis revisited. Nat Rev Cancer 3: 453-458. http://dx.doi.org/10.1038/nrc1098.

[27]Gilchrest BA, Eller MS (2009) Cancer therapeutics: Smart and smarter. Drugs $\quad$ Future, 205-216 http://dx.doi.org/10.1358/dof.2009.034.03.1336071

[28]Grella GE, Cabras MC, Murineddu G, Pau A, Pinna GA (2003) Synthesis and cytotoxicity of substituted 2-benzylnaphth [2, 3d]imidazoles. Eur J Pharm Sci 20: 267-272. http://dx.doi.org/10.1016/S0928-0987 (03)00197-0.

[29]Gribble G W (1990) the Alkaloids, Vol. 39, ed. by Brossi A, Academic Press, New York, pp. 239-352.

[30] [30] Haider N, Kabicher T, Käferböck J, Plenk A (2007) Synthesis and In-vitro Antitumor Activity of 1-[3-(Indol-1-yl)prop-1-yn-1yl]phthalazines and Related Compounds. Molecules 12: 1900-1909. http://dx.doi.org/10.3390/12081900.

[31]Haider N (2002) Pyridazine-Fused Carbazoles: Synthesis, Reactivity, and Antitumor Activity. J Heterocycl Chem 39: 511-521. http://dx.doi.org/10.1002/jhet.5570390307.

[32]Haider N, Jbara R, Khadami F, Wanko R (1998) Synthesis of Pyridazino[4,5-b]carbazoles as Potential Antineoplastic Agents Heterocycles 48: 1609-1622. http://dx.doi.org/10.3987/COM-98-8217.

33]Haider N, Käferböck J (2004) Intramolecular [4+2] cycloaddition reactions of indolylalkylpyridazines: synthesis of annulated carbazoles. Tetrahedron 60:

6495-6507. http://dx.doi.org/10.1016/j.tet.2004.06.008.

[34]Haider N, Käferböck J, Mátyus P (1999) Diels-Alder Reaction of Pyrano[3,4-b]indolones with an Electron-Deficient Pyridazinone: a New Pathway to Carbazole-Fused Pyridazines. Heterocycles, 51 2703-2710. http://dx.doi.org/10.3987/COM-99-8695.

[35]Haider N, Sotelo E (2002) 1, 5-Dimethyl-6H-pyridazino [4, 5b]carbazole, a 3-Aza Bioisoster of the Antitumor Alkaloid Olivacine. Chem Pharm Bull 50(11): 1479-1483. http://dx.doi.org/10.1248/cpb.50.1479.

[36]Hamel E (1984) Antimitotic drugs and tubulin-nucleotide interactions In. R. I. Glazer (ed.), Developments in Cancer Chemotherapy, pp. 131-164.Boca Raton, FL: CRC Press.

[37] Hamel E, Lin CM (1983) Interactions of combretastatin, a new plant derived antimitotic agent, with tubulin. Biochem. Pharmacol, 32 3864-3867. http://dx.doi.org/10.1016/0006-2952 (83)90163-6.

[38]Hamel E, Lin CM (1984) Guanosine 5'-O-(3-thiotriphosphate), a potent nucleotide inhibitor of microtubule assembly. J. Biol. Chem. 259: 11060-11069.

[39]Husain A, Drabu S, Kumar N, Alam MM, Ahmad A (2011) Synthesis and biological evaluation of some new pyridazinone derivatives. J En $\begin{array}{lllll}\text { Inhib } \quad \& \quad \text { Med } & \text { Chem 26(5): }\end{array}$ http://dx.doi.org/10.3109/14756366.2010.548810.

[40]Huwe A, Mazitschek R, Giannis A (2003) Small Molecules as Inhibitors of Cyclin-Dependent Kinases. Angew Chem, Int. Ed. 42: 2122 2138. http://dx.doi.org/10.1002/anie.200200540.

[41]Jiang JK, Boxer MB, Vander Heiden MG, Shena M, Skoumbourdis AP, Southall N, Veith H, Leister W, Austin CP, Parke HW, Inglese J Cantley LC, Auld DS, Thomas CJ (2010). Evaluation of Thieno[3,2 b]pyrrole[3,2-d]pyridazinones as Activators of the Tumor Cell Specific M2 Isoform of Pyruvate. Kinase. Bioorg \& Med Chem Lett 20 (11) 3387-3393. http://dx.doi.org/10.1016/j.bmcl.2010.04.015.

[42]Knockaert M, Greengard P, Meijer L (2002) Pharmacological Inhibitors of Cyclin-Dependent Kinases. Trends Biochem Sci 23: 417-425.

[43]Luduena RF, Fellous A, McManus L, Jordan MA, Nunez J (1984) Contrasting roles of tau and microtubule-associated protein 2 in the vinblas tine-induced aggregation ofbrain tubulin. J Biol Chem 259 1289-12898

[44]Malinka W (2001) Synthesis of some pyrrolo[3,4-d]pyridazinones and their preliminary anticancer, antimycobacterial and CNS screening. Pharmazie 56(5): 384-9.

[45]Malinka W, Redzicka A, Lozach O (2004). New derivatives of pyrrolo[3,4-d] pyridazinone and their anticancer effects. Farmaco 59(6): 457-62. http://dx.doi.org/10.1016/j.farmac.2004.03.002.
[46] Malumbre M, Barbacid M (2001) To Cycle or Not To Cycle: A Critical Decision in Cancer. Nat. Rev. Cancer 1: 222-231. http://dx.doi.org/10.1038/35106065.

[47]McGrath CF, Pattabiraman N, Kellogg GE, Lemcke T, Kunick C, Sausville EA, Zaharevitz D W, Gussio R (2005) Homology Model of the CDK1/Cyclin B Complex. J Biomol Struct Dyn 22: 493-502. http://dx.doi.org/10.1080/07391102.2005.10531227.

[48] Meijer L, Frajolet M, Greengard P (2004) Pharmacological inhibitors of glycogen synthase kinase-3. Trends Pharmacol Sci 25: 471-480. http://dx.doi.org/10.1016/j.tips.2004.07.006.

[49]Mizens M, Brown WR, Killeen JC Jr, Ignatoski JA (1985) Subchronic feeding study in rats with five pyridazinone compounds structurally related to DS-29399. Toxicologist, 5: 60.

[50]Mizens M, Brown WR, Laveglia J, Killeen JC Jr, Ignatoski JA (1984) Combined 30-day feeding study and one-generation reproduction study in rats with ethyl 5-cyano-3,4-diphenyl-6-oxo-1-6HJpyridazineacetate (DS 29399). Toxicologist 4: 17.

[51]Monks A, Scudiero D, Skehan P, Shoemaker R, Paull KD, Vistica D, Hose C, Langley J, Cronise P, Vaigro-Wolff A (1991) Feasibility of a high-flux anticancer drug screen using a diverse panel of cultured human tumor cell lines. J Natl Cancer Inst 83: 757-766. http://dx.doi.org/10.1093/jnci/83.11.757

[52] Murineddu G, Cignarella G, Chelucci G, Loriga G, Pinna GA (2002) Synthesis and cytotoxic activities of pyrrole[2,3-d]pyridazin-4-one derivatives. Chem Pharm Bull 50: 754-759. http://dx.doi.org/10.1248/cpb.50.754.

[53]Norbert H, Eddy S (2002) 1, 5-Dimethyl-6H-pyridazino[4,5b]carbazole, a 3-Aza Bioisoster of the Antitumor Alkaloid Olivacine. Chem Pharm Bull 50(11): 1479-1483. http://dx.doi.org/10.1248/cpb.50.1479

[54]Pau A, Asproni B, Boatto G, Grella GE, De Caprariis P, Costantino L, Pinna GA (2004) Synthesis and aldose reductase inhibitory activities of novel thienocinnolinone derivatives. Eur J Pharm Sci 21: 545-552. http://dx.doi.org/10.1016/j.ejps.2003.12.005

[55]Pau A, Murineddu G, Asproni B, Murruzzu C, Grella GE, Pinna GA Curzu MM, Marchesi I, Bagella L (2009) Synthesis and Cytotoxicity of Novel Hexahydrothienocycloheptapyridazinone Derivatives. Molecules 14, 3494-3508. http://dx.doi.org/10.3390/molecules14093494.

[56]Paull KD, Shoemaker RH, Hodes L, Monks A, Scudiero DA, Rubinstein L, Plowman J, Boyd MR (1989) Display and analysis of patterns of differential activity of drugs against human tumor cell lines: development of mean graph and COMPARE algorithm. J Natl Cancer Inst 81 1088-1092. http://dx.doi.org/10.1093/jnci/81.14.1088.

[57]Pinna GA, Curzu MM, Murineddu G, Chelucci G, Cignarella G, Menta E, Krell HW, Rastelli G, Ferrari AM (2000) Preparation of thieno[3,2-H]cinnolinones as matrix metalloproteinase inhibitors. Arch Pharm Pharm Med Chem 333: 37-47. http://dx.doi.org/10.1002/ (SICI) 1521-4184(200002)333:2/3<37: AID-ARDP37>3.0.CO; 2-V.

[58]Pinna GA, Murineddu G, Murruzzu C, Zuco V, Zunino F, Cappelletti G, Artali R, Cignarella G, Solano L, Villa S (2009) Synthesis, modelling, and antimitotic properties of tricyclic systems characterised by a 2-(5-Phenyl-1H-pyrrol-3-yl)-1,3,4-oxadiazole moiety. Chem Med Chem 4: 998-1009. http://dx.doi.org/10.1002/cmdc.200800428.

[59]Pinna GA, Salis E, Berta D, Gavini E (1997) Synthesis and pharmacological evaluation of 4amethyl-4,4a,5,6-tetrahydrothieno[2,3h]cinnolin-3(2H)-ones. Farmaco 52: 29-33.

[60]Pirisi MA, Murineddu G, Mussinu JM, Pinna GA (2002) Synthesis and cytotoxicity evaluation of thiophene analogues of 1-methyl-2, 3bis(hydroxymethyl)benzo[g]indole bis[N-(2- propyl)carbamate] Farmaco 57: 331-335 http://dx.doi.org/10.1016/S0014 827X(02)01201-6.

[61] Rakib EM, Abouricha S, Hannioui A, Benchat N, Ait M'barek L, Zyad A (2006) Synthesis and in vitro Cytotoxicity Studies of Novel Triazolo[4,3-b]pyridazinones. J Iranian Chem Soc 3(3): 2006, 272 276. http://dx.doi.org/10.1007/BF03247219.

[62]Rathish IG, Javed K, Ahmad S, Bano S, Alam MS, Akhter M, Pillai V, Ovais S, Samim M (2012). Synthesis and evaluation of anticancer activity of some novel 6-aryl-2-(p-sulfamylphenyl)-pyridazin-3(2H)ones. Eur J Med Chem, 49: 304-309. http://dx.doi.org/10.1016/j.ejmech.2012.01.026.

[63] Sedlacek HH, Czech J, Naik R, Kaur G, Worland P, Losiewicz M, Parker B, Carlson B, Smith A, Senderowicz A, Sausville E (1996) Flavopiridol (L86-8275, NSC-649890), a New Kinase Inhibitor for Tumor Therapy. Int J Oncol 9: 1143-1168.

[64] Senderowicz AM, Headlee D, Stinson SF, Lush RM, Kalil N, Villalba L, Hill K, Steinberg SM, Figg WD, Tompkins A, Arbuck SG, Sausville EA (1998) Phase I Trial of Continuous Infusion Flavopiridol, a Novel Cyclin-Dependent Kinase Inhibitor, in Patients with Refractory Neoplasms. J Clin Oncol 16: 2986-2999. 
[65]Sielecki TM, Boylan JF, Benfield PA, Trainor GL (2000) Cyclin Dependent Kinase Inhibitors: Useful Targets in Cell Cycle Regulation. J Med Chem 43, 1-18. http://dx.doi.org/10.1021/jm990256j.

[66]Silverman RJ (2004) the Organic Chemistry of Drug Design and Drug Action, 2nd ed.; Elsevier Academic Press: Burlington, MA, USA, 1314.

[67]Sims PA, Wong CF, McCammon JA (2003) A Computational Model of Binding Thermodynamics: The Design of Cyclin-Dependent Kinase 2 Inhibitors. J Med Chem 46: 3314- 3325. http://dx.doi.org/10.1021/jm0205043.

[68]Spreitzer H, Pichler A, Holzer W, Kratzel M, Slanz R, Koulouri A, Krenn P, Parrer U, Szieber P (2001) Synthesis of azanaphthoquinone annelated pyrroles. Heterocycles 54, 111-121. http://dx.doi.org/10.3987/COM-98-8401.

[69]Spreitzer H, Puschmann C (2007) Synthesis of Anticancer Compounds, I, "Dual Function" Antitumor Agents Based on Bioreduction and DNA-Alkylation. Monatsh Chem 138: 517-522. http://dx.doi.org/10.1007/s00706-007-0604-7.

[70]Staal GEJ, Rijksen G (1991) Biochemical and molecular aspects of selected cancers. Pretlow, TG; Pretlow, TP., editors. Academic Press; San Diego p. 313 http://dx.doi.org/10.1016/B978-0-12-564498$3.50013-3$.

[71]Teague SJ (2003) Implications of Protein Flexibility for Drug Discovery. Nat Rev Drug Discovery 2: 527-541. http://dx.doi.org/10.1038/nrd1129.

[72]Unsal tan O, Ozadali K, Yes O, Ilyurt, Kayir H, Uzbay T, Balkan A (2011) Synthesis and evaluation of the analgesic activity of some new isoxazolo[4,5-d]pyridazin-4(5H)-one derivatives. Turk J Chem 35: 121-130.

[73]Wang T, Dong Y, Wang LC, Xiang BR, Chen Z, Qu LB (2008). Design, synthesis and structure-activity relationship studies of 6-phenyl-4, 5-dihydro-3(2H)-pyridazinone derivatives as cardiotonic agents. Arzneimittelforschung 58(11): 569-73.

[74]Ward, R. W.; Witherington, J. Pyrazolopyridazine Derivatives, Process for Preparation and Use for the Inhibition of GSK-3 WO03080616, 2003.

[75]Witherington J, Bordas V, Garland SL, Hickey DMB, Ife RJ, Liddle J Saunders M, Smith DG, Ward RW (2003) 5-Aryl-pyrazolo[3,4b]pyridines: Potent Inhibitors of Glycogen Synthase Kinase-3 (GSK3). Bioorg \& Med Chem Lett 13: 1577-1580. http://dx.doi.org/10.1016/S0960-894X (03)00134-3.

[76]Zhou G, Ting PC, Aslanian R, Cao J, Kim DW, Kuang R, Lee JF, Schwerdt J, Wu H, Herr RJ, Zych AJ, Yang J, Lam S, Wainhaus S, Black TA, McNicholas PM, Xu Y, Walker SS (2011). SAR studies of pyridazinone derivatives as novel glucan synthase inhibitors. Bioorg Med Chem Lett. 21(10): 2890-3. http://dx.doi.org/10.1016/j.bmcl.2011.03.083. 